\title{
Management of cytokine release syndrome after chimeric antigen $T$-cell therapy for paediatric relapsed/refractory acute lymphoblastic leukaemia: a case report
}

Frankie WT Cheng ${ }^{1,2}$, MD (CUHK), FHKAM (Paediatrics), Ben S Li³, MD, Grace KS Lam ${ }^{1,2}$, FHKCPaed, HKAM (Paediatrics), KL Hon ${ }^{1,2}$, MD, FAAP, Gavin Joynt ${ }^{4}$, FRCP (Edin), FHKAM (Anaesthesiology), CK Li' ${ }^{1,2,5}{ }^{*}$, MD, FRCPCH

${ }^{1}$ Department of Paediatrics, Prince of Wales Hospital, Hong Kong

${ }^{2}$ Department of Paediatrics and Adolescent Medicine, Hong Kong Children's Hospital, Hong Kong

${ }^{3}$ Department of Hematology \& Oncology, Shanghai Children's Medical Center, Shanghai Jiao Tong University School of Medicine, National Children's Medical Center, Shanghai, China

${ }^{4}$ Department of Anaesthesia and Intensive Care, The Chinese University of Hong Kong, Hong Kong

${ }^{5}$ Department of Paediatrics, The Chinese University of Hong Kong, Hong Kong

* Corresponding author: ckli@cuhk.edu.hk

Hong Kong Med J 2020;26:532-4

https://doi.org/10.12809/hkmj198348

\section{Case report}

The event-free survival rate of standard risk/low-risk childhood acute lymphoblastic leukaemia (ALL) is approaching $90 \%$, but there remains around $10 \%$ to $15 \%$ of children who suffer relapse. ${ }^{1}$ Early relapse of ALL or refractory ALL has a very poor prognosis, even with haematopoietic stem cell transplantation. In recent years, chimeric antigen receptor T-cell (CAR-T) therapy has offered a promising treatment for relapsed/refractory ALL. ${ }^{2}$ At present, CAR-T therapy is not available for ALL patients in Hong Kong. Cytokine release syndrome (CRS) is one of the most challenging complications following CAR-T therapy. We report our experience of four children prescribed CAR-T therapy for relapsed/refractory B-cell ALL.

Between June 2018 and March 2019, four children with relapsed/refractory CD19+ B-cell ALL (aged 1-17 years at first relapse) received CAR-T CD19 therapy at a haematology centre in Shanghai, China. Patients 1, 2, and 3 received autologous CAR-T cell products and patient 4 received allogeneic CAR-T cell products. The patients returned to Hong Kong within 12 hours of CAR-T cell infusion and were cared for at our centre. Their clinical progress and outcome are shown in Tables 1 and 2 .

All patients experienced bone marrow relapses shortly following haematopoietic stem cell transplantation or had refractory leukaemic disease before receiving CAR-T therapy (Table 1). Three patients had a high leukaemic disease burden $(>75 \%$ blast in bone marrow) prior to CAR-T therapy. For presentation of cytokine release syndrome (CRS), the first 10 days was the peak onset time, from 6 hours to 9 days following CAR-T cell infusion. The most common presenting symptoms were high fever with temperature $>39^{\circ} \mathrm{C}$, tachycardia, hypotension, and desaturation. As clinical differentiation from sepsis was difficult, all patients received empirical broadspectrum antibiotics. Patients were managed with oxygen supplementation via a nasal cannula or highflow oxygen when there was desaturation. Inotropic support in the intensive care unit was provided in the presence of hypotension. No child required invasive ventilatory support. Systemic steroid was prescribed only to patient 4 who had grade 3 CRS. No patient developed neurotoxicity and all were discharged from the intensive care unit.

Three patients (patients 1, 3, and 4) succumbed to disease relapse 2 to 8 months after CAR-T therapy. One patient (patient 2) remained disease-free for 9 months after CAR-T therapy with satisfactory Lansky performance score.

\section{Discussion}

Chimeric antigen receptor T-cell therapy is a promising novel therapeutic option for relapsed and refractory CD19+ B-cell ALL in children and young adults. ${ }^{2}$ Cytokine release syndrome and neurotoxicity are the two most severe complications of CAR-T therapy. This has been reported to occur any time in the first 2 weeks after infusion of CAR-T cells. Up to $45 \%$ to $91 \%$ of patients develop CRS including serious CRS in $8.3 \%$ to $43 \%$ of cases. ${ }^{3}$ The ASBMT (American Society for Blood and Marrow Transplantation) consensus grading system for CRS is based on the assessment of three vital signs: temperature, blood pressure, and oxygen saturation. Patients with fever (temperature $>38^{\circ} \mathrm{C}$ ) alone constitute grade $1 \mathrm{CRS}$; patients with fever and hypotension without the need for a vasopressor are considered grade 2; patients with fever, hypotension requiring vasopressor and/ or hypoxia requiring oxygen supplementation are grade 3 . In grade 4 CRS, patients have fever with 
TABLE I. Demographics of patients prescribed CAR-T therapy for ALL

\begin{tabular}{|c|c|c|c|c|c|c|c|}
\hline Patient & Sex & $\begin{array}{l}\text { Age at } \\
\text { diagnosis } \\
\text { of ALL } \\
\text { (years) }\end{array}$ & Diagnosis & $\begin{array}{c}\text { Risk } \\
\text { group at } \\
\text { diagnosis }\end{array}$ & $\begin{array}{l}\text { Age at first } \\
\text { relapse } \\
\text { (years) }\end{array}$ & $\begin{array}{l}\text { Salvage therapy before CAR-T } \\
\text { therapy }\end{array}$ & Indication for CAR-T therapy \\
\hline 1 & M & 2.1 & CD19+ B-ALL & IR & 2.8 & $\begin{array}{l}\text { Chemotherapy* / 1st BM relapse } \\
\text { and salvage with chemotherapy† / } \\
\text { unrelated cord blood HSCT }\end{array}$ & $\begin{array}{l}\text { 2nd BM relapse at } 2 \text { months } \\
\text { post-HSCT, salvage with } \\
6 \text {-mercaptopurine / methotrexate / } \\
\text { cytarabine / vincristine; 3rd relapse } \\
\text { at } 4 \text { months later then decided for } \\
\text { CAR-T therapy }\end{array}$ \\
\hline 2 & M & 1.8 & CD19+ B-ALL & IR & 2.7 & $\begin{array}{l}\text { Chemotherapy }{ }^{*} \text { / 1st BM relapse } \\
\text { and salvage with chemotherapy† / } \\
\text { blinatumomab / unrelated cord } \\
\text { blood HSCT }\end{array}$ & $\begin{array}{l}\text { 2nd BM relapse at } 4 \text { months post- } \\
\text { HSCT then for CAR-T therapy }\end{array}$ \\
\hline 3 & M & 0.8 & CD19+ B-ALL & IR & 1.5 & $\begin{array}{l}\text { Chemotherapy* / 1st BM relapse } \\
\text { and treated with blinatumomab / } \\
\text { unrelated cord blood HSCT }\end{array}$ & $\begin{array}{l}\text { 2nd BM relapse at } 2 \text { months } \\
\text { post-HSCT, salvage with steroid / } \\
\text { vincristine; 3rd relapse at } 3 \text { months } \\
\text { later then for CAR-T therapy }\end{array}$ \\
\hline 4 & M & 15.5 & CD19+ B-ALL & IR & 17.0 & $\begin{array}{l}\text { Chemotherapy* / 1st BM relapse } \\
\text { and salvage with chemotherapy } \dagger\end{array}$ & $\begin{array}{l}\text { 2nd BM relapse after clofarabine / } \\
\text { etoposide / cyclophosphamide } \\
\text { then for CAR-T therapy }\end{array}$ \\
\hline
\end{tabular}

Abbreviations: B-ALL = B-cell acute lymphoblastic leukaemia; BM = bone marrow; CAR-T = chimeric antigen receptor T-cell; HSCT = haematopoietic stem cell transplantation; $\mathrm{IR}=$ intermediate risk

* Treated with Chinese Children's Cancer Group childhood acute lymphoblastic leukaemia 2015 study group (CCCG-ALL-20I5) protocol

† Treated with Hong Kong Paediatric Haematology and Oncology Study Group ALL Relapse 2007 Protocol

TABLE 2. Presentation and management of CRS after CAR-T therapy

\begin{tabular}{|c|c|c|c|c|c|c|c|}
\hline Patient & $\begin{array}{l}\text { Delay of } \\
\text { onset of CRS } \\
\text { after CAR-T } \\
\text { therapy }\end{array}$ & Presentation & $\begin{array}{l}\text { Grading } \\
\text { of CRS }\end{array}$ & $\begin{array}{l}\text { Highest } \\
\text { interleukin-6 } \\
\text { level } \\
(<3.1 \mathrm{pg} / \mathrm{mL})\end{array}$ & Management of CRS & $\begin{array}{l}\text { Intensive care } \\
\text { needed }\end{array}$ & Outcome \\
\hline 1 & $\begin{array}{l}6 \text { Hours after } \\
\text { infusion }\end{array}$ & $\begin{array}{l}\text { Fever }\left(39^{\circ} \mathrm{C}\right) \text {, } \\
\text { tachycardia } \\
\text { (HR=160 beats/min), } \\
\text { desaturation }(\mathrm{SaO} 2 \\
85 \%)\end{array}$ & Grade 2 & $\begin{array}{l}357 \text { (Day } 1 \text { of } \\
\text { CAR-T) }\end{array}$ & $\begin{array}{l}\text { Empirical antibiotics, } \\
1 \text { dose of tocilizumab } \\
\text { given at } 7 \text { hours from } \\
\text { onset CRS, oxygen } \\
\text { supplement }\end{array}$ & $\begin{array}{l}\text { Yes } \\
\text { Inotrope - } \\
\text { Oxygen + } \\
\text { Ventilator - }\end{array}$ & $\begin{array}{l}\text { CRS subsided, no } \\
\text { neurotoxicity, died at } \\
2 \text { months post-CAR-T } \\
\text { due to relapse and } \\
\text { septicaemia }\end{array}$ \\
\hline 2 & 9 Days & $\begin{array}{l}\text { Fever }\left(39^{\circ} \mathrm{C}\right) \text {, } \\
\text { tachycardia, } \\
\text { headache, } \\
\text { transaminitis }\end{array}$ & Grade 1 & - & $\begin{array}{l}\text { Empirical antibiotics, } \\
2 \text { doses of tocilizumab }\end{array}$ & $\begin{array}{l}\text { Yes } \\
\text { Inotrope - } \\
\text { Oxygen - } \\
\text { Ventilator - }\end{array}$ & $\begin{array}{l}\text { CRS subsided, no } \\
\text { neurotoxicity, in remission } \\
\text { at } 9 \text { months post-CAR-T; } \\
\text { Lansky performance } \\
\text { score } 90\end{array}$ \\
\hline 3 & 9 Days & $\begin{array}{l}\text { Fever }\left(39^{\circ} \mathrm{C}\right) \text {, } \\
\text { tachycardia, } \\
\text { desaturation ( } \mathrm{SaO} 2 \\
88 \%) \text { with oxygen } \\
\text { supplement }\end{array}$ & Grade 2 & $\begin{array}{l}3929 \text { (Day } 9 \text { of } \\
\text { CAR-T) }\end{array}$ & $\begin{array}{l}\text { Empirical antibiotics, } \\
1 \text { dose of tocilizumab, } \\
\text { oxygen supplement }\end{array}$ & $\begin{array}{l}\text { Yes } \\
\text { Inotrope - } \\
\text { Oxygen + } \\
\text { Ventilator - }\end{array}$ & $\begin{array}{l}\text { CRS subsided, no } \\
\text { neurotoxicity, in remission } \\
\text { until } 5 \text { months post- } \\
\text { CAR-T, died at } 8 \text { months } \\
\text { post-CAR-T therapy } \\
\text { owing to relapse; Lansky } \\
\text { performance score } 70-80 \\
\text { at disease-free period }\end{array}$ \\
\hline $4^{*}$ & $\begin{array}{l}3 \text { Hours after } \\
\text { infusion }\end{array}$ & $\begin{array}{l}\text { Fever }\left(39.5^{\circ} \mathrm{C}\right) \text {, } \\
\text { hypotension, chills, } \\
\text { rigor, desaturation } \\
\text { (SaO2 } 80 \%) \text { with } \\
\text { oxygen supplement, } \\
\text { oliguria }\end{array}$ & Grade 3 & $\begin{array}{l}9746 \text { (Day } 1 \text { of } \\
\text { CAR-T) }\end{array}$ & $\begin{array}{l}\text { Empirical antibiotics } \\
2 \text { doses of tocilizumab, } \\
\text { given } 1 \text { day from onset } \\
\text { CRS, methylprednisolone } \\
\text { for } 2 \text { days, inotropes }\end{array}$ & $\begin{array}{l}\text { Yes } \\
\text { Inotrope }+ \\
\text { High-flow oxygen }+ \\
\text { Ventilator - }\end{array}$ & $\begin{array}{l}\text { CRS subsided, no } \\
\text { neurotoxicity, died at } \\
2.5 \text { months post-CAR-T } \\
\text { owing to relapse and } \\
\text { septicaemia }\end{array}$ \\
\hline
\end{tabular}

Abbreviations: CAR-T = chimeric antigen receptor T-cell; CRS = cytokine release syndrome; $\mathrm{HR}=$ heart rate; $\mathrm{SaO} 2=$ oxygen saturation

* Received allogeneic CAR-T therapy

hypotension requiring multiple vasopressors and trial or as standard treatment using commercial positive pressure ventilation. ${ }^{4}$

CAR-T cell products. The treatment will soon be

In recent years many centres in Western introduced in Hong Kong so local experience of countries and mainland China have started to managing CRS will be of interest to our readers. provide CAR-T therapy, either as part of a clinical

Cytokine release syndrome is a systemic 
inflammatory response that can be triggered by a variety of factors such as infection and certain drugs. The term "cytokine release syndrome" was first used in the early 1990s when the anti-T-cell antibody muromonab-CD3 (OKT3) was introduced as an immunosuppressive treatment for solid organ transplantation. Recently, with the success of the newer T-cell-engaging immunotherapy, namely blinatumomab, there has been a refocus on CRS since it represents one of the most frequent serious complications. ${ }^{5}$ The clinical features of CRS sometimes overlap with those of haemophagocytic lymphohistiocytosis or macrophage activation syndrome. $^{6}$ In our cohort, the peak onset was observed in the first 10 days following CAR-T therapy. A high disease burden prior to CAR-T therapy may be associated with severe CRS. Close monitoring and early intervention are key for successful control of CRS. Remaining alert for this condition and timely institution of monoclonal antibody against interleukin-6 receptor (tocilizumab $8 \mathrm{mg} / \mathrm{kg}$; $12 \mathrm{mg} / \mathrm{kg}$ if body weight $<30 \mathrm{~kg}$ ), or adding systemic steroid in severe cases together with intensive cardiorespiratory support is the recommended treatment for CRS. ${ }^{3,4}$ Institutes are advised to have tocilizumab readily available prior to commencement of CAR-T therapy since timely control of CRS by this agent is vital to prevent progression of cytokine storm. The mortality of CRS has now been much reduced with clinicians acquiring more experience in managing complications. Vigorous respiratory and circulatory support in an intensive care unit is also essential. ${ }^{7}$ Gardner et $\mathrm{al}^{3}$ reported that early intervention with tocilizumab and/or systemic steroid in patients with early signs of CRS did not negatively impact the anti-tumour potency of CD19 CAR-T therapy.

Our treatment outcome seems inferior to that reported in the literature in which 3-month remission rate was $81 \% ; 73 \%$ at 6 months and $50 \%$ at 12 months. ${ }^{2}$ In our cohort, two patients (50\%) remained in disease remission at 3 months whereas only one (25\%) was in remission 9 months post-CAR-T therapy. However, the case number is small and comprised of patients with multiple relapses, three of whom developed relapse after haematopoietic stem cell transplantation and one who had very refractory disease. These patients are well known to be a group with one of the worst prognoses and most individuals do not survive long-term.

Some centres utilise CAR-T therapy as a bridge before transplantation as consolidative therapy for relapsed or refractory ALL. Unfortunately, in our four patients, three were at a very early posttransplant stage and would be unable to tolerate a second transplant. In other case scenarios, namely those with chemorefractory ALL, CAR-T therapy may play a role in bridging prior to hematopoietic stem cell transplantation. Recent clinical trials have adopted alternative CAR-T therapy strategies such as bispecific or sequential CAR-T therapy that may have a more potent anti-leukaemic effect. ${ }^{8}$

In conclusion, early recognition of CRS and early intervention with vigorous cardiopulmonary support and timely initiation of anti-interleukin-6 receptor therapy can achieve good control of CRS. Chimeric antigen receptor T-cell therapy is now offered as a new salvage therapy for patients with relapsed/refractory CD19+ B-acute lymphoblastic leukaemia.

\section{Author contributions}

Concept or design: BS Li, CK Li.

Acquisition of data: FWT Cheng, GKS Lam, G Joynt, KL Hon. Analysis or interpretation of data: FWT Cheng.

Drafting of the manuscript: FWT Cheng.

Critical revision of the manuscript for important intellectual content: CK Li.

\section{Conflicts of interest}

As an editor of the journal, KL Hon was not involved in the peer review process. The other authors have disclosed no conflicts of interest.

\section{Funding/support}

This case report received no specific grant from any funding agency in the public, commercial, or not-for-profit sectors.

\section{Ethics approval}

The patient was treated in accordance with the tenets of the Declaration of Helsinki. The patient provided written informed consent for all treatments and procedures.

\section{References}

1. Cheng FW, Lam GK, Cheuk DK, et al. Overview of treatment of childhood acute lymphoblastic leukemia in Hong Kong. HK J Paediatrics (New Series) 2019;24:184-91.

2. Maude SL, Laetsch TW, Buechner J, et al. Tisagenlecleucel in children and young adults with B-cell lymphoblastic leukemia. N Engl J Med 2018;378:439-48.

3. Gardner RA, Ceppi F, Rivers J, et al. Preemptive mitigation of CD19 CAR T-cell cytokine release syndrome without attenuation of anti-leukemic efficacy. Blood 2019;134:214958.

4. Neelapu SS. Managing the toxicities of CAR T-cell therapy. Hematol Oncol 2019;37:48-52.

5. Kantarjian H, Stein A, Gökbuget N, et al. Blinatumomab versus chemotherapy for advanced acute lymphoblastic leukemia. N Engl J Med 2017;376:836-47.

6. Crayne C, Cron RQ. Pediatric macrophage activation syndrome, recognizing the tip of the iceberg. Eur J Rheumatol 2019:1-8.

7. Hon KL, Luk MP, Fung WM, et al. Mortality, length of stay, bloodstream and respiratory viral infections in a paediatric intensive care unit. J Crit Care 2017;38:57-61.

8. Wang N, Hu X, Cao W, et al. Efficacy and safety of CAR19/22 T-cell cocktail therapy in patients with refractory/relapsed B-cell malignancies. Blood 2020;135:17-27. 